\title{
Study on the Identification and Protection of the Historical Landscape of Traditional Settlements of the De'ang Nationality Based on the Theory of Rural Landscape Heritage
}

\author{
Dongqiang Zhang ${ }^{1}$ Haiyan $\mathrm{Li}^{2}$,*
}

\begin{abstract}
${ }^{1}$ School of Fine Arts \& Design, Baoshan University, Baoshan, Yunnan 678000, China
${ }^{2}$ School of Engineering and Technology, Baoshan University, Baoshan, Yunnan 678000, China

*Corresponding author. Email: zhangdqvip1985@163.com
\end{abstract}

\begin{abstract}
Traditional villages are the pacesetters in the construction of beautiful villages and the promotion of rural revitalization strategies, and the carriers of the relationship between traditional farming culture and rural life. Since 2011, the International Federation of Landscape Architect (IFLA) and the International Council for Monuments and Sites (ICOMOS) launched the "World Rural Landscape Initiative" (WRLI), and "Principles Concerning Rural Landscape as Heritage (2017)" was adopted by the International Council for Monuments and Sites (ICOMOS), "rural landscape heritage" has been elevated from a technical term to a theory and method to explore the conservation of landscape heritage. Based on this theory, this article takes the traditional Chinese village, the settlement of De'ang nationality in Pinghe, as an example. Through field research and interview with the residents, it is possible to identify the distribution and characteristics of its natural, settlement and cultural landscape heritage, and explore the protection of rural landscape heritage, with a view to providing practical experience for the construction of beautiful countryside.
\end{abstract}

Keywords: rural landscape, rural landscape heritage, De'ang nationality, traditional settlement

\section{INTRODUCTION}

On October 18, 2017, the strategy of rural revitalization was put forward in the report of the 19th National Congress of the Communist Party of China: "the issues of agriculture, rural areas, and rural residents are fundamental problems related to the national economy and the people's livelihood, so we must always take the issue of solving problems related to agriculture, rural areas, and rural residents as the top priority of the party's work, and implement the strategy of rural revitalization." The ultimate goal of rural revitalization is to continuously improve the participation and benefits of villagers in the industrial development, thoroughly solve the problems of rural industry and farmers' employment, and ensure the longterm stability of local people's income growth and living in peace and contentment. In September 2012, the ministry of housing and urban rural development, the ministry of culture and the ministry of finance publicized the list of the first batch of Chinese

*Project: Scientific Research Fund of Education Department of Yunnan Province Funding Project "Study on the Identification and Adaptability of Rural Landscape Features of De'ang Traditional Villages" (2020J0701). traditional villages. By 2019, five batches of 6799 traditional villages have been published, and there are 709 traditional villages in Yunnan Province, which is one of the most typical traditional village clusters. Traditional villages are the vanguard for the construction of beautiful villages and the promotion of rural revitalization strategy, and the carrier of the relationship between traditional farming culture and rural life. The traditional villages have rich historical and cultural landscape heritage. Especially, for the settlements inhabited by ethnic minorities, rural landscape is the symbol of their national culture and regional culture. How to excavate and identify the historical landscape heritage and give full play to its heritage value in the process of rural revitalization are "hot issues" worthy of further exploration.

The deepening of the concept and connotation of "rural landscape" and "rural landscape as heritage" is mainly due to ICOMOS's attention to cultural heritage throughout the 20th century. From the Athens Charter (1931), the Venice Charter (1964) to the Krakow Charter (2000), the focus of various heritages has gradually shifted from the cultural relics protection units with architecture as the main body to various 
heritage objects related to daily life [1], [2], [3], [4]. The studies on rural landscape heritage in China and foreign countries mainly focus on the heritage and cultural value of landscape, practice of rural landscape at regional and national level, continuous cultural landscape, taking rural landscape as heritage, biocultural diversity, land use system and landscape, etc. Especially at the end of the 20th century, Charter on the protection and restoration of cultural heritage issued by ICOMOS put forward landscape as a cultural heritage for the first time. Experts in China and foreign countries began to realize that landscape and cultural heritage witnessed human development, and rural landscape heritage also received attention. In 1984, the French delegation put forward the concept of "rural landscape" at the ICOMOS conference held in Buenos Aires: "historically, since the Neolithic age, human planting activities have transformed the land on a large scale and changed the original ecosystem..." [5] In 1987, at the world heritage conference, the concept of "mixed heritage site" was proposed, and it believed that the rural landscape was a part of it according to its definition of both "cultural and natural properties". In 1992, the "guidelines for the implementation of the world heritage convention" put rural landscape into the category of "organically evolving landscape" of cultural landscape. The "guidelines on rural landscape heritage" issued by ICOMOS-IFLA was adopted at the nineteenth ICOMOS conference in India at the end of 2017. It is a preliminary result of the theme research work of "global rural landscape initiative" launched by the Specialized Committee of Cultural Landscape in 2011 [6]. The "guidelines" define rural landscape as multi-functional resources, which refer to the land and water areas formed under the interaction between human and nature. Through the collection, hunting and mining of a series of resources, food and renewable natural resources can be produced. In particular, the definition of rural landscape has been expanded boldly: "all rural areas are landscapes", which gives cultural significance to people and communities living in rural areas. Rural landscape heritage is a summary of rural landscape heritage in the past period of time, which provides solid theoretical research methods and practical guidance methods for rural landscape heritage research and practice in the future.

\section{IDENTIFICATION METHOD OF HISTORICAL LANDSCAPE HERITAGE OF TRADITIONAL SETTLEMENTS}

Rural landscape contains rich ecological wisdom, production and life relations, land use and farming technology, as well as traditional farming culture. As a dynamic and continuous evolution landscape, it is changing all the time. In recent years, scholars in China and foreign countries focus on the identification, evaluation and protection of rural landscape characteristics and heritage value. The identification methods mainly focus on the quantitative aspects such as surface coverage map, two-dimensional map and geographic information system, "source-sink" theory, aviation remote sensing image and so on. In the aspect of qualitative identification and evaluation, AHP method, landscape gene, HLC systems and so on are mainly focused. The above methods pay more attention to the construction of rural landscape on the graph, while the regionality and value continuity of rural landscape heritage are rarely involved.

Based on the inherent relationship between "accumulation layer by layer" and "value relevance" presented by "rural landscape" and "rural landscape as heritage", this paper pays more attention to the problem of building rural landscape by human behavior, and tries to use the traditional field survey, mapping and resident interview, which are subjective identification methods, and explores features and heritage protection of rural landscape with the protection and development planning of research object. The survey mainly includes three aspects (see "Table I"): natural landscape heritage (including historical data, traditional village location pattern and surrounding environment and other resources), settlement landscape heritage (including traditional buildings, historical environment elements and other tangible traditional resources) and cultural landscape heritage (including intangible traditional resources such as intangible cultural heritage owned by the village, as well as the planning, policies and management systems related to the protection and development of traditional villages, etc.)

TABLE I. RURAL LANDSCAPE HERITAGE IDENTIFICATION BASED ON FIELD SURVEY AND RESIDENT INTERVIEW

\begin{tabular}{|c|c|c|c|}
\hline \multicolumn{2}{|c|}{ Investigation topics } & Content of investigation & Identification requirements \\
\hline \multirow{2}{*}{$\begin{array}{l}\text { Natural } \\
\text { landscape } \\
\text { heritage }\end{array}$} & $\begin{array}{l}\text { Village } \\
\text { environment }\end{array}$ & $\begin{array}{l}\text { Natural environment, cultural relics and scenic spots within the } \\
\text { village }\end{array}$ & \multirow{2}{*}{$\begin{array}{l}\text { Forming topographic map of } \\
\text { recent mapping elements (no less } \\
\text { than 1:5000) }\end{array}$} \\
\hline & $\begin{array}{l}\text { Location and } \\
\text { pattern }\end{array}$ & $\begin{array}{l}\text { Village landform, mountain and river system, land use, main } \\
\text { living texture space, etc }\end{array}$ & \\
\hline \multirow[t]{2}{*}{$\begin{array}{l}\text { Settlement } \\
\text { landscape } \\
\text { heritage }\end{array}$} & $\begin{array}{l}\text { traditional } \\
\text { architecture }\end{array}$ & $\begin{array}{l}\text { The location, age, area, basic shape, construction technology, } \\
\text { structural form, main materials, decoration features and } \\
\text { functional changes of traditional buildings }\end{array}$ & \multirow{2}{*}{$\begin{array}{l}\text { Forming a spatial analysis } \\
\text { diagram (no less than 1:2000), and } \\
\text { making a detailed analysis } \\
\text { diagram of the main historical } \\
\text { environment elements }\end{array}$} \\
\hline & $\begin{array}{l}\text { Elements of } \\
\text { historical } \\
\text { environment }\end{array}$ & $\begin{array}{l}\text { Elements reflect the historical features of villages and constitute } \\
\text { the characteristics of villages. Focusing on the investigation of } \\
\text { tower bridge and pavilion, wellspring and ditch, stone terrace }\end{array}$ & \\
\hline
\end{tabular}




\begin{tabular}{|c|c|c|c|}
\hline & & $\begin{array}{l}\text { paving, wharf revetment, stele building and stone carving, } \\
\text { ancient and famous trees, and traditional industrial heritage } \\
\text { facilities, etc. }\end{array}$ & \\
\hline \multicolumn{2}{|c|}{ Investigation topics } & Content of investigation & Identification requirements \\
\hline \multirow[t]{3}{*}{$\begin{array}{l}\text { Cultural } \\
\text { landscape } \\
\text { heritage }\end{array}$} & $\begin{array}{l}\text { Immaterial } \\
\text { culture }\end{array}$ & $\begin{array}{l}\text { Traditional representative projects, production and life styles, } \\
\text { rural customs and places, buildings, utensils, etc. }\end{array}$ & $\begin{array}{l}\text { Recording its nature, generation, } \\
\text { development and evolution } \\
\text { process, inheritance status, scale } \\
\text { of mass participation, } \\
\text { management and protection status, } \\
\text { etc. }\end{array}$ \\
\hline & Documentation & $\begin{array}{l}\text { All kinds of local records, genealogies, historical maps, } \\
\text { inscriptions, deeds, tablets and couplets, village evolution, } \\
\text { changes, important people, major historical events, etc. }\end{array}$ & \multirow{2}{*}{$\begin{array}{l}\text { The main information is arranged } \\
\text { and compiled by means of } \\
\text { shooting, scanning, classification } \\
\text { and analysis. }\end{array}$} \\
\hline & $\begin{array}{l}\text { Conservation } \\
\text { and } \\
\text { development } \\
\text { information }\end{array}$ & $\begin{array}{l}\text { Management organization, township rules and regulations, } \\
\text { financial support, development planning, and village social } \\
\text { environment, etc. }\end{array}$ & \\
\hline
\end{tabular}

\section{TYPES AND CHARACTERISTICS OF THE HISTORICAL LANDSCAPE HERITAGE OF TRADITIONAL SETTLEMENTS OF THE DE'ANG NATIONALITY}

\section{A. Natural landscape heritage}

Pinghe village is located in Gaoligong Mountain, with an average altitude of 1800 meters, annual average temperature of $25{ }^{\circ} \mathrm{C}$, and annual precipitation of 900 $\mathrm{mm}$. The settlement is surrounded by mountains and the Yanjiahe River passes through the village. The dwellings are concentrated in the north-west of the Yanjiahe River, facing north and locating in the south. Farmland and production forest land are crisscross distributed around the village, showing a ladder pattern of fronting water and with hills on the back: "mountain — settlement — productive field" decrease layer by layer. In the process of village expansion, the original residential pattern will not be damaged. The village development will be built along the contour line, and the residential pattern will be maintained according to the mountain. The settlement takes the "vein-shaped" water system as the skeleton, and the whole village presents a three-dimensional spatial pattern of "mountain group - water vein - industrial patch street network".

The settlement is divided into four areas in a cluster style, in which the water network and forest fields are staggered. The whole settlement is in an ideal gourd environment, with Huangyan mountain and Lunzi mountain as the barrier in the east, Liangzi mountain in the south, Gouben mountain and Huangiandi mountain in the northwest, and the exit of Yanjia river and the village in the northeast corner, and separated by a large area of walnut feng-shui forest. The road into the village twists and turns. The natural landscape heritage of the village is mainly composed of the landscape wisdom, feng-shui forest, Yanjiahe corridor, "stilt" building group, herb planting field, fruit planting and cultivation patch under the forest.

\section{B. Settlement landscape heritage}

In the term of architectural form, the original appearance of the traditional buildings and the surrounding environment of the settlement is well preserved. There are 86 traditional courtyards, which are basically built in the Qing Dynasty, with concentrated distribution and coordinated style. The typical public buildings are Lingshan temple and Jisitai (sacrifice), which were built in Ming Dynasty. The traditional architecture has the typical symbiotic characteristics of the De'ang nationality and the Han nationality. To a great extent, it retains the style of the stilt bamboo house of the De'ang nationality. In terms of the roof and decoration, the architecture of Han nationality is the main one. The building structures are all bamboo and wood structures, adopting the traditional architectural style of "one principal room and two wing-rooms", sitting in the west and facing the east, and existing along the contour line in the form of steps ("Fig. 1" and "Fig. 2"). In the term of architectural function, the principal rooms are on the first floor and occupy the highest position, mainly including the hall and bedrooms. Two wing-rooms are built on both sides, and are often used as the kitchen or utility room. The wing room is built on the second floor, with stilt structure. Poultry is often kept on the bottom floor, and grains and grass are piled on the second floor. The gate is to the east or north. In the term of building roof and decoration, the roof is consisted of double slope with green tile or grass of the Han nationality. The wall is the most distinctive part, mainly composed of earth wall, rubble, wood pile, bamboo fence and wood board, which fully reflects the regional construction characteristics of the De'ang people living in high mountains and taking local materials. The doors and windows of the building are made of bamboo and wood, mainly of hollow cross lattice and plum lattice. In the term of building color and material, the building color is mainly the primary color of materials, mainly earthy yellow and gray. The building materials are displayed in the texture of raw materials, without anticorrosion treatment such as paint. 


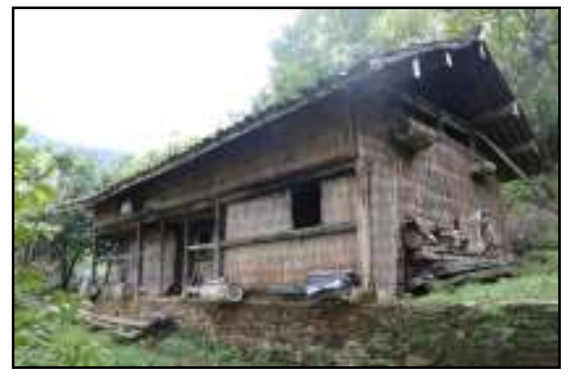

Fig. 1. Features of single building of principal room.

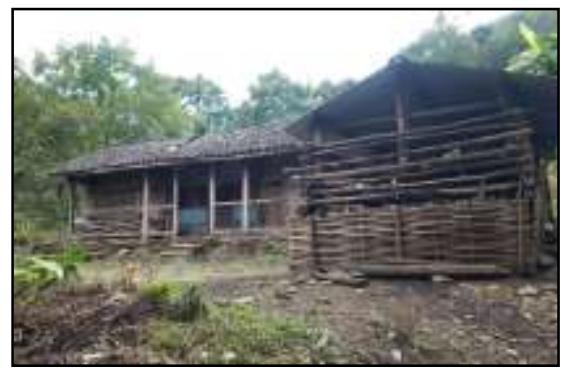

Fig. 2. The combination of architectural courtyard.

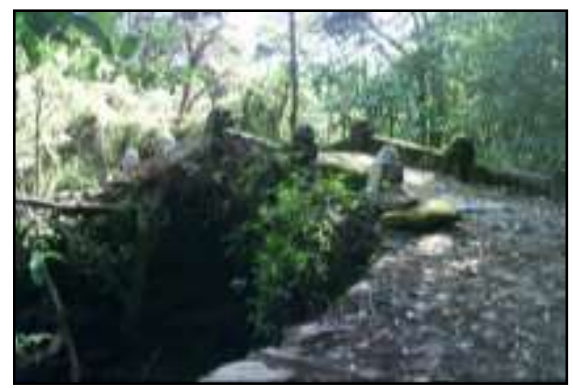

Fig. 3. Ancient bridge.

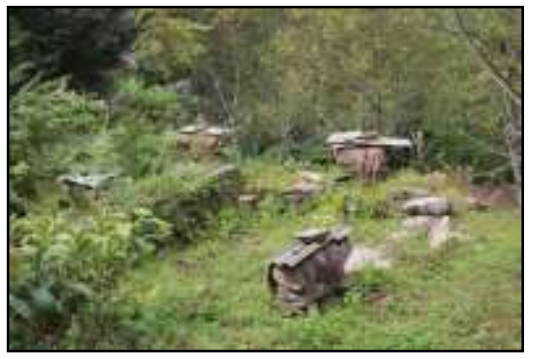

Fig. 4. Bee farm.

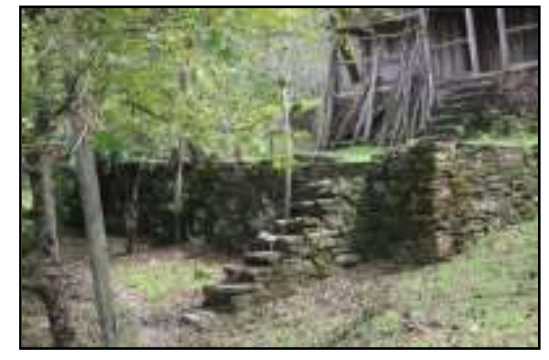

Fig. 5. Ancient courtyard.

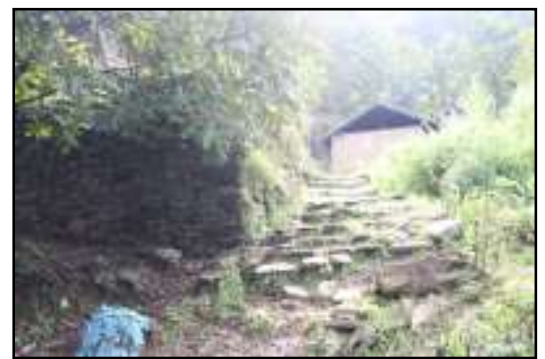

Fig. 6. Ancient path.

Historical environment elements are an important part of the whole rural landscape heritage. Through field survey and mapping, it is found that the historical environment elements left are basically built in the Ming and Qing Dynasties, mainly divided into three categories (as shown in "Table II", "Fig. 3", "Fig. 4", "Fig. 5", "Fig. 6"): public infrastructure (including bridges and culverts, ancient roads and ancient canals, etc.), elements serving agricultural production (including bee farms, sun farms, ancient courtyards and characteristic herbs planting land) and elements serving residents' life (including ancient courtyard, ancient steps and ancient water tanks). These are carriers of the continuation of traditional farming culture, and are organically linked with each other through production and life style, forming an industrial chain with ecological wisdom.

TABLE II. IMPORTANT HISTORICAL ENVIRONMENTAL PROTECTION ELEMENTS

\begin{tabular}{|l|l|l|l|l|l|}
\hline Environment element & Quantity (set) & Environment element & Quantity (PCs.) & $\begin{array}{l}\text { Environment } \\
\text { element }\end{array}$ & $\begin{array}{l}\text { Quantity } \\
\text { (piece/ piece) }\end{array}$ \\
\hline Lingshan Temple & 1 & Ancient well & 4 & Yingpan river & 2 \\
\hline Huaqiao in Pinghe & 3 & $\begin{array}{l}\text { Ancient drainage } \\
\text { channel }\end{array}$ & 8 & Ancient steps & 13 \\
\hline Ancient culvert & 4 & Ancient water vat & 2 & Ancient woods & 17 \\
\hline Ancient tombstone & 6 & Bee farm & 18 & Ancient path & 7 \\
\hline Ancient stonewalling & 11 & Ancient courtyard & 46 & Herb planting land & 12 \\
\hline
\end{tabular}




\section{Cultural landscape heritage}

Cultural landscape heritage mainly includes intangible culture, literature, protection and development materials, all of which reflect the production and life culture of the De'ang nationality ("Table III") and show the characteristics of the De'ang nationality. There are many elements in the traditional folk cultural activities of the De'ang nationality: the cultural square with a long history, traditional festivals and folk activities, folk literature, Chinese folk art forms, musical instruments, ballads, dance, painting, handicrafts, clothing, utensils and so on with historical, scientific, cultural and artistic values of the De'ang nationality, the original national literature with historical, cultural and artistic values, such as Atlas, music score, dance, novel, legend and ballad, as well as inheritors of traditional national culture.

TABLE III. IMPORTANT INTANGIBLE CULTURAL HERITAGE

\begin{tabular}{|l|l|l|l|}
\hline Type & Main Features & Type & Main Features \\
\hline De'ang dialect & Bulei, Rumai, Ruojin & dance & Water-drum Dance, eight-step dance \\
\hline $\begin{array}{l}\text { Traditional } \\
\text { clothing }\end{array}$ & Tube skirt and story & marriage & Singing folk songs and playing Lusheng \\
\hline Festival Program & $\begin{array}{l}\text { Ghost tree sacrifice, dragon king sacrifice, } \\
\text { snake god sacrifice }\end{array}$ & wushu & Counter punch \\
\hline Craftsmanship & Carving, drum competition, architecture & diet & corn, bamboo shoots, wild vegetables, medicinal herbs \\
\hline
\end{tabular}

\section{PROTECTION OF THE HISTORICAL LANDSCAPE HERITAGE OF TRADITIONAL SETTLEMENTS OF THE DE'ANG NATIONALITY}

\section{A. Protection of natural landscape heritage based on the improvement of human settlement}

Comprehensive improvement of human settlements is the best way to protect and continue the natural landscape heritage. The traditional village of De'ang nationality in Pinghe has a very regional and characteristic settlement environment. According to the issued village protection and development plan, the forests and basic farmland around the settlement should be protected strictly, the rivers and water sources in the settlement area should be controlled, and some wasteland should be planted with trees and converted to forests. In the process of expanding the construction land, the settlement should respect the group layout and gourd pattern, improve the quality of feng-shui forest in the village entrance, and strictly protect the environmental pattern of "mountain settlement farmland". According to the concept of original site protection, the historical environment elements left in the settlement are classified and registered, listed for protection. It is required to combine with rural tourism experience to create characteristic landscape nodes, such as listing to protect ancient trees, carrying out popular science education, properly developing bee farms and tourism experience on the premise of ensuring safety.

\section{B. Protection of settlement landscape heritage based on rural tourism development}

Traditional architectural complex is the core part of the settlement landscape heritage, and the repair and protection are the key to maintain the national characteristics of the settlement. It is necessary to rely on the development of rural tourism, appropriately change the use function, and take measures to make the protection, reservation, improvement and renewal. In the term of protection, it is necessary to establish construction protection archives, take strict protection measures for the gathering areas with good construction quality and style, allow the replacement and arrangement of individual components, repair the old as it is, and truthfully reflect the value of historical relics. In the term of reservation, for buildings newly built and repaired in recent years, those with little conflict between architectural style and environment can maintain the status quo and increase the regional facade finishing. In the term of improvement, for the traditional buildings with serious damage and partial loss of use function, the courtyard pattern and style of the buildings shall be protected, the external environment shall be controlled, and the interior of the buildings shall be transformed according to the use demand. In the term of renewal, buildings with uncoordinated style, potential fire hazard, dilapidated structure and disorderly construction shall be demolished and renewed.

This paper explores the sustainable development path of the industrial part maintaining the livelihood among the historical environment elements of settlements by adapting to modern agriculture. Part of the agricultural industry and intangible cultural industry in the settlement have formed a certain scale, and there are many industries with single structure. Therefore, it is necessary to take adaptive measures to adjust and improve the industrial structure. The industries with certain scale in the settlement are mainly walnut, white papaya, Chonglou, sealwort, Amomum tsao-ko and konjak planting, as well as bee, cattle and native chicken breeding. It is necessary to upgrade and restructure its industry, adopt the modern agricultural concept, build a comprehensive industrial chain, construct a circular agricultural industry, and enhance the value of the traditional industry of the old village. At the same time, it is required to use the Internet 
platform to jointly promote the "online and offline" sales channels of the agricultural industry with certain scale.

\section{Protection of cultural landscape heritage based on cultural creativity activation}

The intangible cultural heritage can be classified for live display. For the cultural heritage of folk activities, the "song and dance" tourism cultural festival can be held with the help of mobile Internet such as douyin, kuaishou, etc. For the cultural heritage of craft and products, it can build a village museum, carry out craft experience, or make tourism cultural and creative product development and promotion. In addition, all kinds of cultural heritage can increase the added value of the industry by relying on cultural tourism experience services, and make the promotion through the form of "Internet + cultural innovation", so as to create an experiential tourism integrating experiential agriculture, cultural festivals, hiking expeditions, popular science education and rural museums, and realize the value enhancement of traditional industries.

\section{Conclusion}

National culture and rural culture are important parts of Chinese culture, and also the driving force of the development of traditional villages. Rural landscape is its living carrier. Based on the theory of rural landscape heritage, field survey and resident interview are the most effective identification methods to survey the types of rural landscape and explore the regional characteristics. Taking the traditional settlement of De'ang nationality as a case, this paper explores the identification and protection methods of rural landscape heritage in the process of preparing the protection plan, classifies the rural landscape heritage into natural, settlement and cultural landscape heritage, and then puts forward the protection approaches based on the improvement of human settlements, rural tourism development and cultural creativity activation. This is a practical exploration. The ways to build a beautiful countryside and revitalize the countryside should be diversified and individualized, especially for the settlements of the ethnic minority. In the exploration and practice, more attention should be paid to regional culture and residents' participation willingness.

\section{References}

[1] Le Goff J. DocumentoMonumento[M]/Enciclopedia Einaudi, 1978: 38-48

[2] Choay F. L'Allegorie du patrimoine, Paris, 1992; Italian trans. L'Allegoria del patrimonio, Rome, 1995.

[3] L ennon J. Cultural L andscape management:international influences[M]/Taylor $\mathrm{K}, \mathrm{L}$ ennon J.Managing Cultural L andscapes. London: Routledge, 2012: 45-69
[4] Goetcheus C, Mitchell N. The Venice Charter and cultural landscapes: evolution of heritage concepts and conservation over time[J]. Change Over Time, 2014, 12(2): 338- 357

[5] [litaly] Lionella Scazzosi, Wang Xi. Li Jingyu. Cbntexts and Concept of Principles Concerning Rural Landscape as Heritage ICOMOS (2017)[J]. Chinese Landscape Architecture, 2018, 11(5): 5-9.

[6] ICOMOS China.Principles Concerning Rural Landscape as Heritage, ICOMOS, 2017. 